$$
\text { MT-DP - 2018/9 }
$$

Does response time predict withdrawal decisions?

\author{
Lessons from a bank-run experiment
}

HUBERT JÁNOS KISS

ISMAEL RODRIGUEZ-LARA

ALFONSO ROSA-GARCIA 


$$
\begin{aligned}
& \text { Discussion papers } \\
& \text { MT-DP - 2018/9 }
\end{aligned}
$$

Institute of Economics, Centre for Economic and Regional Studies, Hungarian Academy of Sciences

KTI/IE Discussion Papers are circulated to promote discussion and provoque comments.

Any references to discussion papers should clearly state that the paper is preliminary. Materials published in this series may subject to further publication.

Does response time predict withdrawal decisions?

Lessons from a bank-run experiment

\author{
Authors: \\ Hubert János Kiss \\ Research fellow in the Momentum (LD-004/2010) \\ Game Theory Research Group \\ Institute of Economics, Centre for Economic and Regional Studies, \\ Hungarian Academy of Sciences \\ Department of Economics, Eötvös Loránd University, Budapest, Hungary. \\ email: hubert.kiss@tatk.elte.hu \\ Ismael Rodriguez-Lara \\ Department of Economics, Middlesex University London, UK \\ email: I.Rodriguez-Lara@mdx.ac.uk.
}

\begin{abstract}
Alfonso Rosa-Garcia
Facultad de Ciencias Jurídicas y de la Empresa, Universidad Católica San Antonio, Murcia, Spain email: arosa@ucam.edu
\end{abstract}

May 2018 


\title{
Does response time predict withdrawal decisions? Lessons from a bank-run experiment
}

\author{
Hubert János Kiss - Ismael Rodriguez-Lara - Alfonso Rosa-Garcia
}

\begin{abstract}
We study how response time in a laboratory experiment on bank runs affects withdrawal decisions. In our setup, the bank has no fundamental problems, depositors decide equentially (if to keep the money in the bank or to withdraw) and may observe previous decisions depending on the information structure. We consider two levels of difficulty of decisionmaking conditional on the presence of strategic dominance and strategic uncertainty. We posit that i) decisions in information sets characterized by the lack of strategic dominance are more difficult than in those with strategic dominance; ii) in the latter group, decisions are more difficult when there is strategic uncertainty. We investigate how response time associates with the difficulty and optimality of withdrawal decision. We hypothesize that a) the more difficult the decision, the longer the response time; b) the predictive power of response time depends on difficulty. We find that response time is longer in information sets with strategic uncertainty compared to those without (as expected), but we do not find such relationship when considering strategic dominance (contrary to our hypothesis). Response time correlates negatively with optimal decisions in information sets with a dominant strategy (contrary to our expectation) and also when decisions are obvious in the absence of strategic uncertainty (in line with our hypothesis). When there is strategic uncertainty, we find suggestive evidence that response time predicts optimal decisions. Thus, freezing deposits for some time may be beneficial and help to avoid massive withdrawals as it engthens response times.
\end{abstract}

Keywords: bank run, cognitive abilities, coordination games, dominant strategy, experiment, response time, sequential rationality, strategic uncertainty

JEL classification: C72, C91, D80, G21 


\section{Acknowledgements}

Hubert János Kiss gratefully acknowledges financial support from the the Hungarian Scientific Research Fund (OTKA) under project 109354, the János Bolyai Research Scholarship of the Hungarian Academy of Sciences and the National Research, Development and Innovation (NKFIH) under the project K 119683. This research was supported by the Higher Education Institutional Excellence Program of the Ministry of Human Capacities in the framework of the 'Financial and Public Services' research project (17833/2018/FEKUTSTRAT) at Corvinus University of Budapest. Ismael Rodriguez-Lara and Alfonso Rosa-Garcia acknowledge financial support from the Spanish Ministry of Economics under research projects ECO2014-58297-R. 


\section{Előrejelzi a válaszidő a betétesi döntéseket? Egy bankroham-kísérlet tanulságai}

Kiss Hubert János - Ismael Rodriguez-Lara - Alfonso Rosa-Garcia

\section{Összefoglaló}

Egy laboratóriumi kísérlet segítségével azt tanulmányozzuk, hogyan hat a válaszidő a betétesi döntésekre. A kísérletben a banknak nincsenek fundamentális problémái, a betétesek egymás után döntenek, hogy kivegyék-e a pénzüket a bankból, és az információs struktúra függvényében megfigyelhetik az előző döntéseket. A döntéshozatal két nehézségi fokát vizsgáljuk, amelyeket a domináns stratégiák, illetve a stratégiai bizonytalanság jelenléte okoznak. Azt várjuk, hogy i) nehezebb dönteni akkor, amikor nincs domináns stratégia; ii) amikor van domináns stratégia, akkor a döntés stratégiai bizonytalanság mellett nehezebb, mint annak hiányában. A következő hipotéziseket fogalmazzuk meg a válaszidő hossza és a betétesi döntések nehézségével és optimalitásával kapcsolatban: a) minél nehezebb a döntés, annál hosszabb a válaszidő; b) a válaszidő prediktív ereje a nehézségtől függ. Azt találjuk, hogy a válaszidő hosszabb olyan domináns stratégiával rendelkező döntési helyzetekben, amelyeket stratégiai bizonytalanság jellemez (ahogy vártuk), de nem találunk összefüggést a válaszidő és a domináns stratégia jelenléte között (szemben a várakozásainkkal). A válaszidő negatívan korrelál az optimális döntésekkel olyan döntési helyzetekben, amelyekben van domináns stratégia (várakozásainkkal ellentétben) és akkor is, amikor a döntés nyilvánvaló a stratégiai bizonytalanság hiányában (ahogy vártuk). Stratégiai bizonytalanság mellett meggyőző bizonyítékot találunk amellett, hogy a válaszidő előrejelzi az optimális döntéseket. A betétkifizetések felfüggesztése így hasznos lehet, hogy elkerüljük a tömeges betétkivétet, hiszen ez megnöveli a válaszidőt.

Kulcsszavak: bankroham, domináns stratégia, kísérlet, kognitív képességek, koordinációs játék, stratégiai bizonytalanság, válaszidő

JEL kódok: C72, C91, D80, G21 


\title{
Does response time predict withdrawal decisions? Lessons from a bank-run experiment*
}

\author{
Hubert Janos Kiss ${ }^{\dagger}$ \\ MTA KRTK KTI and Eötvös Loránd University \\ Ismael Rodríguez-Lara ${ }^{\ddagger}$ \\ Middlesex University London \\ Alfonso Rosa-García ${ }^{\S}$ \\ Universidad Católica San Antonio de Murcia
}

May 12, 2018

\begin{abstract}
We study how response time in a laboratory experiment on bank runs affects withdrawal decisions. In our setup, the bank has no fundamental problems, depositors decide sequentially (if to keep the money in the bank or to withdraw) and may observe previous decisions depending on the information structure. We consider two levels of difficulty of decisionmaking conditional on the presence of strategic dominance and strategic uncertainty. We posit that i) decisions in information sets characterized by the lack of strategic dominance are more difficult than in those with strategic dominance; ii) in the latter group, decisions are more difficult when there is strategic uncertainty. We investigate how response time associates with the difficulty and optimality of withdrawal decision. We hypothesize that a) the more difficult the decision, the longer the response time; b) the predictive power of response time depends on difficulty. We find that response time is longer in information sets with strategic uncertainty compared to those without (as expected), but we do not find such
\end{abstract}

\footnotetext{
*Hubert Janos Kiss gratefully acknowledges financial support from the the Hungarian Scientific Research Fund (OTKA) under project 109354, the János Bolyai Research Scholarship of the Hungarian Academy of Sciences and the National Research, Development and Innovation (NKFIH) under the project K 119683 . This research was supported by the Higher Education Institutional Excellence Program of the Ministry of Human Capacities in the framework of the 'Financial and Public Services' research project (1783-3/2018/FEKUTSTRAT) at Corvinus University of Budapest. Ismael Rodriguez-Lara and Alfonso Rosa-Garcia acknowledge financial support from the Spanish Ministry of Economics under research projects ECO201458297-R.

${ }^{\dagger}$ MTA KRTK - Research fellow in the Momentum (LD-004/2010) Game Theory Research Group. Department of Economics, Eötvös Loránd University, Lágymányosi Campus, 1117 Budapest, Hungary. E-mail address: hubert.kiss@tatk.elte.hu.

${ }^{\ddagger}$ Department of Economics, Middlesex University London, Hendon Campus, The Burroughs, London NW4 4BT, United Kingdom. Email address: I.Rodriguez-Lara@mdx.ac.uk.

${ }^{\S}$ Facultad de Ciencias Jurídicas y de la Empresa, Universidad Católica San Antonio. Campus de Los Jerónimos, s/n Guadalupe 30107, Murcia, Spain. Phone: +34968278662 Email: arosa@ucam.edu
} 
relationship when considering strategic dominance (contrary to our hypothesis). Response time correlates negatively with optimal decisions in information sets with a dominant strategy (contrary to our expectation) and also when decisions are obvious in the absence of strategic uncertainty (in line with our hypothesis). When there is strategic uncertainty, we find suggestive evidence that response time predicts optimal decisions. Thus, freezing deposits for some time may be beneficial and help to avoid massive withdrawals as it lengthens response times.

Keywords: bank run, cognitive abilities, coordination games, dominant strategy, experiment, response time, sequential rationality, strategic uncertainty

JEL Classification: C72, C91, D80, G21.

\section{Introduction}

There were numerous bank runs during the last financial crisis that started in 2007 with the run on Northern Rock, an English bank. Run-like phenomena affected also money-market, hedge and pension funds (Baba, McCauley and Ramaswamy, 2009), the repo market (Gorton and Metrick, 2012) and even bank lending (Ivashina and Scharfstein, 2010). Hence, understanding the nature of bank runs would help to prevent the unfolding of such events in all these settings in the future.

Descriptions of real bank runs illustrate how depositors rush to the bank, often trying to withdraw their money as fast as possible. This situation creates the queues in front of the banks that have become a symbol of economic and financial crisis. However, existing studies have not delved into the relation between bank run situations and the speed of decision-making. Moreover, nothing is known about if (too) fast responses are related to the emergence of bank run-like situations. This study investigates these questions with an experimental approach, analyzing the relation between response time and withdrawal decisions of different difficulty that can provoke or spread a bank run.

When a bank run is underway and depositors rush to the bank to withdraw their funds, the banking authority responds in many instances by suspending the convertibility (also known as freezing the deposits). Such a suspension has many roles, one of which is to allow to make more informed and less hurried decisions. If in a fundamentally healthy bank a run is caused by panicky and hastened decisions that moreover turn out to be contagious, then the imposed suspension may help to stop the massive withdrawal. Our study can be seen as an indirect test to see in a controlled environment if panicky decisions result in withdrawals and bank runs.

Our laboratory framework resembles a situation where bank runs may occur under different circumstances. In particular, in our framework there is an impatient depositor who withdraws immediately and there are two patient depositors who decide whether to withdraw or to keep the money deposited. Depositors take their decisions in different information structures, that vary according to the decisions that can be observed. ${ }^{1}$ In our experimental model, bank runs may

\footnotetext{
${ }^{1}$ It resembles different types of situations: in some cases depositors decide in a physical queue so they observe actions of their predecessors, in other cases depositors completely ignore what other depositors are doing (e.g. in case of online banking). The run on Northern Rock is an illustration of the first case, while the 'silent run' on Washington Mutual exemplifies the
} 
occur only due to coordination problems between depositors and potentially those coordination problems arise due to hurried and not sufficiently premeditated decisions. If both patient depositors keep their funds deposited, then it gives them the largest payoff, and leads to the social optimum of no bank run. However, if only one of them does so, then withdrawal yields a larger payoff (except for the last position, as we explain later) and there is a bank run.

When depositors make decisions during a bank run, there are different situations that imply different cognitive load. We assume that decision-making is easiest when there is a dominant strategy and at the same time there is no strategic uncertainty (that is uncertainty about the choices of the other depositors). Things are more difficult if there is dominant strategy, but also strategic uncertainty. The set of decisions that we consider the most difficult in our setup are those that have no dominant strategy. We study if response time varies with the difficulty of the decision-making. We conjecture that response time is longer in information sets where decision-making is more difficult. In other words, we hypothesize that on average response time i) is shorter when subjects have a dominant strategy than when there is not such a strategy, and ii) when there is a dominant strategy, response time is longer when there is strategic uncertainty relative to when there is not.

The quality of decisions associated to different response times may also have a key importance in bank run situations. Thus, we also explore how response time correlates with the decision of keeping the funds deposited or withdrawing the money from the bank. We expect that when there is a dominant strategy and no strategic uncertainty, then response time has no predictive power because decision-making is very straightforward and not much mental effort and deliberation is needed to find the optimal choice. In this case, actually longer response time may be seen as a signal of not understanding the situation. However, as decisions become more difficult, response time may have an explanatory power. More precisely, we speculate that in information sets with strategic uncertainty and with a dominant strategy longer response time may go together with better decisions. If this is the case, it would suggest that faster decisions can be associated with poor financial decisions that can lead to runs in banks with no fundamental problems.

Suboptimal decisions may lead to considerable economic losses. ${ }^{2}$ A straightforward explanation of suboptimal decision-making is that real-life individuals do not act as rationally as the homo oeconomicus in the standard economic models. Potentially, the reason is that cognitive abilities are in shorter supply than the theory assumes. In fact, there is a growing literature that studies how cognitive abilities relate to financial decision-making (e.g. Korniotis and Kumar 2010). ${ }^{3}$ In this study we control in regressions for cognitive abilities (measured

second case.

${ }^{2}$ There are numerous examples that potentially are due to poor financial decision making. For instance, Gerardi et al. (2013) claim that mortgage defaults in the US housing market that propelled the last economic downturn were associated with numerical ability. In the case of retirement plans, Choi et al. (2011) and van Rooij et al. (2011) present evidence showing that individuals forego arbitrage profits by making suboptimal investment choices. Bertrand and Morse (2011) point out that some individuals do not collect sufficient information (even though relevant information is available) about the real costs of the loan from payday lenders, and take up extremely expensive loans from them

${ }^{3}$ We show in an earlier study (Kiss et al., 2016) that cognitive abilities in fact affect decision-making in a bank-run experiment. 
by the Cognitive Reflection Test, see Frederick (2005)), so we can investigate if beyond cognitive abilities the length of the response time correlates with the optimality of decisions. ${ }^{4}$

In our data, we find that response time does not vary with strategic dominance. We do find support for our hypothesis regarding the effect of strategic uncertainty: response time is longer in information sets with strategic uncertainty than in information sets without it. Regarding the relationship between response time and the optimality of depositor decisions, in the absence of strategic uncertainty decisions response time associates negatively with optimal choices, indicating that those who take longer to decide seemingly do not understand the situation and make bad decisions. However, when there is some difficulty in the decision (that in our case is equivalent to have an environment with strategic uncertainty), then we have suggestive evidence that response time is positively related with optimal decisions. This lends support to deposit freezes because this can be seen as a way to lengthen the response time and so lead to better decisions.

The rest of the paper is structured as follows. Section 2 contains the literature review. In section 3 , first we present the experimental setup, then we describe our hypotheses. We report our findings in section 4 . Section 5 concludes.

\section{Literature review}

Our study relates to two strands of literature: bank runs and response time. Regarding bank runs, we are not aware of any paper that investigates how the response time measured in experiments is associated with the difficulty and the optimality of decisions. We hope that our study will spark more interest on this issue. We review here briefly the role of strategic uncertainty in bank run models and experiments. In the canonical Diamond-Dybvig (1983) framework there are multiple equilibria, one of them involving bank run, because depositors best respond to belief about the other depositors' choices. Hence, one may argue that pervasive strategic uncertainty in the form of a simultaneoues-move game is behind that result. ${ }^{5}$ We have a sequential model in the sense that depending on the underlying social network depositors have the opportunity to observe previous decisions and it should alleviate the problem. Kiss et al. (2014a) show in the same environment as we have in this paper that if depositors in position 1 and 2 are linked, then theoretically we should not have bank runs in equilibrium. However, in the lab they observe bank runs, so it is of interest to see if the absence of strategic uncertainty and the time taken to decide affect if a patient depositor withdraws. That is what we do in this paper.

In fact, the fast-growing literature on response time analysis in experimental economics suggests that researchers should pay more attention to this underused additional variable that is available at zero cost in most lab experiments. Economists ignored response time, even though psychologists started to measure thinking time quite early (e.g. Donders 1868). Spiliopoulos and Ortmann (2017)

\footnotetext{
${ }^{4}$ Jimenez et al. (2018) show that response time correlates positively with the Cognitive Reflection Test.

${ }^{5}$ Kinateder and Kiss (2014) show that if the game is completely sequential and all previous decisions can be observed, then the run equilibrium disappears.
} 
argue convincingly that the reason for it was the substantive (or outcome-based) rationality paradigm proposed by many mainstream economists (for example, Friedman 1953) that claims that the optimal choice of an individual given her goals and constraints can be derived independently of the decision-making process (of which time may be an important ingredient). In contrast, proponents of procedural (or process-based) rationality (e.g. Simon 1976) assert the importance of decision-making processes and associated constraints. Many arguments can be brought up in defence of using response time to understand decisionmaking. Spiliopoulos and Ortmann (2017) claim for instance that ecological and external validity of experiments is harmed by neglecting response time. Moreover, there may be a trade-off between response time and the optimality of decision.

Spiliopoulos and Ortmann (2017) review the existing literature and show that the studies in which response time was measured and used as explanatory variable utilized mainly well-known games: ultimatum game, public-goods game, dictator game and the p-beauty contest. We contribute to the literature by considering a new game: the bank-run game, that is essentially a coordination game with two types. In the literature, in many instances response time is significantly associated with choices, outcomes and payoffs. For example, Arad and Rubinstein (2012) find that longer response time correlates with higher average payoffs in an experiment using the Colonel Blotto game. Rand et al. (2012) and Lotito et al. (2013) report that response time and contribution in the public-goods game are negatively related. This suggests that cooperation is an intuitive choice and longer thinking leads to more selfish decisions. ${ }^{6}$ Piovesan and Wengström (2009) find that lower response time correlates with selfish choices in the dictator game. Rubinstein (2007) shows that shorter response time is related with more intuitive choices and less sophisticated reasoning in different games and reports considerable heterogeneity in response time across individuals. Rubinstein (2013) reports that in the case of non-strategic tasks with an objective correct answer, the longer is the response time, the less errors are commited.

Related to this last example, one of the most basic question is if there is a trade-off between the speed and the optimality of the response. To be able to come up with an answer to this question, one needs to have clear correct and erroneous choices. Fortunately, in our bank-run game a patient depositor has a dominant strategy in many information sets. For example, given the payoffs it is clearly optimal to keep the money in the bank whenever another depositor has decided to do so and her decision is observable. Moreover, as argued before, even if there is a dominant strategy, in the presence of strategic uncertainty a more sophisticated strategic reasoning is required, so there we expect that it may take longer to reach the optimal decision. In information sets with a dominant strategy, but without strategic uncertainty, decisions are simple, there quick decisions may not imply errors.

Spiliopoulos and Ortmann (2017) claim that it is important to thoroughly map the speed-optimality relationship for classes of strategic games. Knowing in which class of games is the trade-off present would inform for instance the design of institutions. Our contribution in this respect is clear as we study

\footnotetext{
${ }^{6}$ Tinghög et al. (2013) claim that this finding does not hold when taking into account subjects who did not answer on time. When correcting for these individuals, there is no clear relationship between contribution levels and response time.
} 
a coordination game with and without strategic dominance and strategic uncertainty, a class of game that - to the best of our knowledge - has not been investigated from the vantage point of response time.

Another relevant piece of research is Rubinstein (2016) that proposes a typology of players based on the classification of their actions as instinctive or contemplative. ${ }^{7}$ Importantly, classification is based on response time, contemplative / instinctive players take more / less time to respond than the median response time. The use of response time to classify choices as instinctive or contemplative is related to Kahneman (2011) who distinguishes between system I decision processes (quick and instinctive responses) and system II decision processes (deliberated and contemplative responses). ${ }^{8}$ Rubinstein gathered data on response time for games played on his website from online players all over the world. He analyzes 10 games i) that were played by many players, ii) that exhibited very different response time distributions for the various actions, iii) for which strategies could be classified clearly as being above or below the median response time. The games included the zero-sum game, Hoteling's Main Street Game, the two-contests game, relying on the other player's rationality, succesive elimination, the ultimatum game, the one-shot chain store game, the centipede game, the stop or pass game and the traveler's dilemma. Choosing the safe / dominated action generally was associated with shorter response time. Importantly, Rubinstein (2016) did not study coordination games with two types, so in this sense our paper is a contribution to the literature. One may wonder, what is the instinctive / contemplative action in our case? In the absence of strategic uncertainty, the choice is simple so there it is not so important the distinction. When strategic uncertainty is present (when nothing / a withdrawal is observed), then withdrawing seems to be the instinctive (and seemingly safe) action.

Branas-Garza et al. (2016) is the closest study to ours, because they investigate how strategic risk (that is equivalent to strategic uncertainty) and response time interact. They use a game with high (ultimatum game) and low (Yes-or-No game) strategic risk to disentangle the effects. They consider response time as a proxy for the amount of deliberation. They find a positive correlation between strategic risk and response time, a result that we share. They also report that the choices of participants with a longer response time is more dispersed than those of subjects with a shorter response time. They find that longer response time associates with less giving in the ultimatum game (which is a more selfish, but also a riskier behavior), while in the Yes-or-No game longer response time correlates with more generous behavior. A clear difference between their study and ours is that very different games are used and it has further consequences. For instance, while in the ultimatum game it is not clear what is the optimal choice (as the participant cannot know the minimum amount that her co-player is willing to accept), in our game we often have a dominant strategy. Relatedly, while our participants face strategic uncertainty in many instances, still they may have a dominant strategy. We show that strategic uncertainty affects decisions even if it should not. ${ }^{9}$

\footnotetext{
${ }^{7} \mathrm{An}$ individual's type is then given as the probability of choosing the contemplative action

${ }^{8}$ Note that slower decisions tend to be contemplative, but the fast-slow dimension is different from the instinctive-contemplative dimension.

${ }^{9}$ In our setup strategic uncertainty only makes the decision more complicated, without altering the optimal choice.
} 


\section{Experimental design and hypotheses}

\subsection{Experimental setup}

Two sessions were run at the LINEEX (University of Valencia) in June 2013 using the z-Tree software (Fischbacher, 2007). There was a total of 60 participants, all undergraduate Economics or Business students of the university who have not taken part in experiments about coordination problems or financial decisions before.

The experiment started with 3 trial rounds so that subjects become familiar with the software and then 15 payoff-relevant rounds followed. ${ }^{10}$ At the beginning of each round, each participant was informed that she had been randomly matched to another participant in the lab, and together with a third depositor (the impatient depositor who was simulated by the computer) they formed a bank.

Each round consists of three periods $t=\{0,1,2\}$. Depositors start in $(t=0)$ with their initial endowment of 80 ECUs deposited in the bank that hence has 240 ECUs. This amount is invested in a project that returns a certain net positive return after two periods $(t=2)$, so there is no fundamental uncertainty about the health of the bank. At $t=1$ the investment can be liquidated without any cost and yielding zero net return.

The computer determines randomly a sequence of decision at $t=1$. Importantly, depositors know their position in the sequence. We call depositor $i$ $(i=1,2,3)$ the depositor who decides in position $i$. Depositors have to decide if to withdraw their money from the bank or to keep it deposited. Table 1 represents the payoffs. Withdrawal yields 100 ECUs immediately as long as the bank has sufficient funds to pay. Therefore, if depositors 1 or 2 withdraw, then each of them receives 100 ECUs with certainty. However, if depositor 3 chooses to withdraw after two withdrawals, then her payoff is only 40 ECUs, because the previous two depositors received a total of 200 ECUs from the bank, that has only 40 ECUs left available. ${ }^{11}$

\begin{tabular}{cc|cc}
\multicolumn{2}{c|}{ Withdrawal } & \multicolumn{2}{c}{ Keeping the money in the bank } \\
\hline $\begin{array}{c}\text { Number of previous } \\
\text { withdrawals }\end{array}$ & Payoff & $\begin{array}{c}\text { Number of other } \\
\text { depositors that do so }\end{array}$ & Payoff \\
\hline \hline 0 & 100 & 0 & 60 \\
1 & 100 & 1 & 140 \\
2 & 40 & &
\end{tabular}

Table 1: Payoffs in the experiment, depending on the decision of other depositors in the same bank

The payoff corresponding to keeping the money deposited depends on how many depositors decide to do so. If there is only one depositor who does not withdraw at $t=1$, then her payoff amounts to 60 ECUs. If two depositors keep their money in the bank, then their payoff is 140 ECUs. ${ }^{12}$

\footnotetext{
${ }^{10}$ We reproduce the instructions in Appendix A. More details on the game can be found in Kiss et al. (2016).

${ }^{11}$ Note that if depositor 3 withdraws after 0 or 1 withdrawal, then the bank can pay her 100 ECUs.

${ }^{12}$ The payoffs reflect the payoffs in Diamond and Dybvig (1983) in that payoff at $t=1$ is
} 
Information about previous choices depends on the information structure that is determined by a set of links among depositors. Link $i j$ for $i, j \in$ $\{1,2,3\}, i<j$ implies that depositor $j$ observes depositor $i$ and depositor $i$ is aware of that fact. For instance, 13 denotes that depositor 1 and depositor 3 are connected; therefore, depositor 1 knows that depositor 3 will observe her choice and that depositor 3 decides after observing depositor 1's choice. Links are independent of liquidity types (patient vs. impatient), so depositors of the same type are not more likely to be linked, nor is there any relationship between types and the number of links. Position and the number of links are also independent (e.g., depositors in position 1 do not have systematically more links that subsequent depositors). We varied the information structure across rounds in an exogenous way. All this information was made clear to the participants at the beginning of the experiment.

Remember that in each bank there is a depositor (simulated by the computer) who is hit by a liquidity shock at $t=1$ and is forced to withdraw, substantially increasing the degree of strategic uncertainty. Imagine a patient depositor who observes a withdrawal. She does not know whether the withdrawal is due to the impatient depositor (i.e., the computer) or a patient depositor (i.e., the other subject in the lab) who chose to withdraw. In a similar vein, when nothing can be observed, a depositor faces strategic uncertainty, because she does not know what the other participant in the lab has decided / is going to do.

Subjects in both sessions were split into three matching groups of 10. At the beginning of each round, subjects within the same matching group were randomly matched in pairs, and participants from different matching groups never interacted with each other. Participants were informed about what happened in their bank (the number of withdrawals and their own payoffs) before being rematched.

For each decision, participants had 30 seconds to respond. Within that time interval subjects could choose when to respond, so our study belongs to the endogenous response time literature. If the participant did not respond on time, then actually they could take more time for decision. The experimenters nudged subtly the participants to the next round only in extreme cases when one or some participant(s) took too much time to decide.

Socio-demographics were collected at the end of the experiment as part of a questionnaire. It included questions regarding gender, risk aversion and cognitive abilities. We used the investment decision in Gneezy and Potters (1997) to elicit risk attitudes. Subjects were asked how much from a hypothetical endowment of 10 Euros they would invest in a risky option and how much they would keep. With $50 \%$ probability the investment returned 2.5 times the invested amount, with $50 \%$ the investment was lost. The money not invested in the risky option increased the earnings of the participant. Note that the expected value of the investment is positive and increasing in the amount invested;

\footnotetext{
higher than the initial deposit and that payoff at $t=2$ gives the maximum payoff if all patient depositor keep their funds deposited. That the last depositor has a dominant strategy to keep her money in the bank is also a consequence of the Diamond-Dybvig setup (and therefore, this feature is present in general in many bank-run model based on their seminal paper). In this setup, the money that has not been withdrawn from the bank early earns some interest as it matures. Thus, even if everybody has withdrawn and the bank still has some money left, it is worthwhile to keep that money deposited instead of withdrawing because of the interest accrued.
} 
therefore a risk-neutral (or risk-loving) participant would invest the 10 Euros, while a risk-averse subject would invest less. Risk aversion can be proxied by the amount not invested in the risky asset. ${ }^{13}$ We used the Cognitive Reflection Test by Frederick (2005) to measure cognitive abilities.

Each session lasted approximately 90 minutes, and average payoff amounted to 15 euros, including a show-up fee of 3 euros. A random lottery incentive procedure was used for the payment, thus one choice (that is, one of the rounds) was randomly paid at the end of the experiment. We used the exchange rate 10 ECUs $=1$ euro.

\subsection{Hypotheses}

We state hypotheses relating the length of response time with the cognitive difficulty that characterizes the decisions, and with the optimality of depositor decisions. We argue that we can group decisions conditional on the presence of strategic dominance and strategic uncertainty. Our first hypothesis is related to the information sets with and without dominant strategies. Given the payoffs (see Table 1), in all information sets in position 3 a patient depositor has a dominant strategy. This is the case, because given the payoffs in that situation keeping the money in the bank is the best strategy, for any possible action of the other patient depositor. At position 2, a patient depositor has a dominant strategy to keep her money in the bank if she observes that depositor 1 did the same, because that gives the maximum payoff. In all other information sets, optimality of strategies depends on actions of the rest of depositors, thus there is no dominant strategy. We conjecture that decisions in information sets without a dominant strategy are more difficult than those with a dominant (and hence straightforward) strategy, and thus we hypothesize longer response times.

Hypothesis 1a - Strategic dominance and response time: We expect to observe longer response times in information sets without dominant strategy than in information sets with dominant strategy.

In our bank-run enviroment, situations with a dominant strategy may have or not have strategic uncertainty, defined as the uncertainty regarding the choice of the other patient depositor. For instance, if a patient depositor in position 3 observes a withdrawal, then she faces strategic uncertainty as the observed choice can be due either to the patient or the impatient depositor. However, she has a dominant strategy, as explained earlier. In contrast, if a patient depositor observes that somebody decided to keep her money in the bank, then she knows with certainty what the other patient depositor did and it makes her decision easier. We hypothesize that decision is more difficult in information sets characterized by strategic uncertainty, and as before we propose that on average depositors need more time to decide in those information sets.

Hypothesis 1b - Strategic uncertainty and response time: In information sets with a dominant strategy, we expect to observe on average longer response times in information sets with strategic uncertainty than in information sets without strategic uncertainty.

\footnotetext{
${ }^{13}$ Crosetto and Filippin (2016) review four risk elicitation methods, among them also the one used by us.
} 
Now we propose hypotheses regarding the effect of response time on optimality of decisions. In the information sets with a dominant strategy, we test if longer deliberation is associated with better decisions, which in this situation means to keep the funds in the bank.

Hypothesis 2a - Response time and optimal decisions when there is a dominant strategy: In information sets with a dominant strategy, we expect a positive correlation between response time and the probability of keeping the money deposited.

In an information set with a dominant strategy and no strategic uncertainty, the decision is obvious. In this case, we consider that a longer response time should be more related with confusion. When there is strategic uncertainty, we can expect that longer response time are associated with a higher deliberation in finding it.

Hypothesis 2b - Response time and optimal decisions conditional on strategic uncertainty: In information sets with a dominant strategy, we expect longer response times to associate with optimal decisions in the presence of strategic uncertainty. When strategic uncertainty is absent, we expect no or negative correlation between response times and decisions.

\section{Results}

Subjects in the experiment took their decision on keeping their funds deposited or withdrawal under different circumstances. In Table 2 and in Table 3 we show the response times and depositor decisions aggregated at the individual level (for each individual, we take the average in each condition, and compare between individuals). As Table 2 shows, response time is very similar with or without a dominant strategy. Individuals who keep their money deposited seem to decide in less time. Table 3 indicates that response time and withdrawal decisions vary much more with respect to the presence of strategic uncertainty.

\begin{tabular}{|c|c|c|c|c|}
\hline & \multicolumn{2}{|c|}{ Dominant strategy } & \multicolumn{2}{|c|}{ No dominant strategy } \\
\hline Observations & \multicolumn{4}{|c|}{$\mathrm{N}=60$} \\
\hline Response time & \multicolumn{2}{|c|}{$19.66(9.72)$} & \multicolumn{2}{|c|}{$19.44(7.42)$} \\
\hline & Keeps deposited & Withdraws & Keeps deposited & Withdraws \\
\hline Observations & $\mathrm{N}=59$ & $\mathrm{~N}=17$ & $\mathrm{~N}=57$ & $\mathrm{~N}=49$ \\
\hline Response time & $19.72(10.01)$ & $22.53(12.91)$ & $19.03(9.04)$ & $24.18(14.02)$ \\
\hline
\end{tabular}

Table 2: Response times in information sets with and without dominant strategy

In what follows, we analyze first the response time of subjects depending on the presence of strategic dominance and strategic uncertainty. We plot the cumulative distribution functions for information sets where they are or are not present, and test differences using the Kolmogorov-Smirnov test. We also compare aggregated choices at the individual level using the Wilcoxon signedrank test.

Then we move to the effects of response time on withdrawal decisions. First, we compare response times of individuals deciding whether to keep the money 


\begin{tabular}{|c|c|c|c|c|}
\hline & \multicolumn{2}{|c|}{ Strategic certainty } & \multicolumn{2}{|c|}{ Strategic uncertainty } \\
\hline Observations & \multicolumn{2}{|c|}{$\mathrm{N}=57$} & \multicolumn{2}{|c|}{$\mathrm{N}=54$} \\
\hline Response time & \multicolumn{2}{|c|}{$17.71(10.48)$} & \multicolumn{2}{|c|}{$20.66(11.07)$} \\
\hline & Keeps deposited & Withdraws & Keeps deposited & Withdraws \\
\hline Observations & $\mathrm{N}=56$ & $\mathrm{~N}=3$ & $N=53$ & $\mathrm{~N}=15$ \\
\hline Response time & $17.43(10.2)$ & 34.89 (17.59) & $21.72(12.61)$ & $20.53(10.62)$ \\
\hline
\end{tabular}

Table 3: Response times in information sets with and without strategic uncertainty

in the bank or to withdraw, using the same procedure than before. Then we add response time as a explanatory variable of withdrawal decision in a regression model where we control for individual characteristics.

\subsection{Strategic dominance, strategic uncertainty and response time}

\subsubsection{Strategic dominance}

Participants in the experiment were reasonable in the sense that in information sets with a dominant strategy (to keep the money in the bank) there are only $9.3 \%$ withdrawals. In information sets without the dominant strategy of keeping the funds deposited the withdrawal rate climbs up to $39.6 \%$.

Hypothesis 1a says that decision in information sets without a dominant strategy is more difficult, so it takes longer to choose in these circumstances. In fact, the average response time corresponding to when there is no dominant strategy (19.67) is longer than when there is (18.83). Note these numbers are the averages of all decisions, without taking into account who made that choice. Figure 1 shows the cumulative distribution function of response time in information sets with and without dominant strategy. The Kolmogorov-Smirnov test detects a weak difference $(\mathrm{p}$-value $=0.095)$ between the two distributions.

Table 2 aggregates observations on the individual level. It shows that the average response time is somewhat longer when there is dominant strategy, but the difference is rather small. In fact, the Wilcoxon signed-rank test does not indicate a significant difference $(\mathrm{p}$-value $=0.7460)$. All these evidence drives us to reject Hypothesis 1a.

Result 1a - Strategic dominance and response time: We do not observe longer response times in information sets without dominant strategy than in information sets with dominant strategy, thus we reject Hypothesis 1a.

Result 1a may indicate that forming beliefs about the other patient depositor's choice may be easier for participants in the lab than figure out that they are in an information set with a dominant strategy, and hence they have an obvious choice. In fact, there are studies documenting that many subjects find it hard in experiments to reason case-by-case and come up with best responses to hypothetical events (e.g. Shafir and Tversky 1992, Esponda and Vespa 2014, Ngangoue and Weizsacker 2015). That is, even though the dominant strategy theoretically seems to make decision easy, finding it may be a cognitively demanding task. This implies that potentially there is some heterogeneity in 


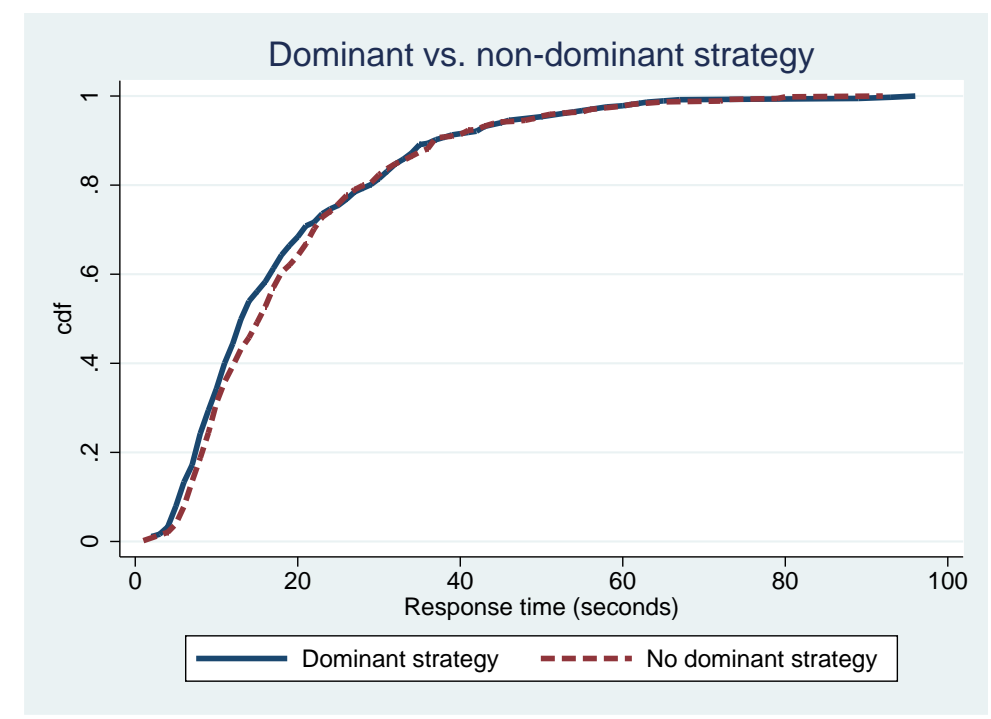

Figure 1: Cumulative distribution function of response times in information sets with and without dominant strategy

the difficulty of decisions within the information sets with a dominant strategy, showing that it makes sense to study the difficulty of decisions along another dimension, for instance strategiy uncertainty.

\subsubsection{Strategic uncertainty}

Regarding the effect of strategic uncertainty, participants in the experiment on average made rational choices because in information sets with a dominant strategy and without strategic uncertainty we observe only $3.3 \%$ withdrawals. In information sets with a dominant strategy, but also with strategic uncertainty the withdrawal rate rises to $17.1 \%$.

Hypothesis $1 \mathrm{~b}$ conjectures that within the set of information sets with dominant strategy it is more difficult to decide when there is strategic uncertainty, so we should observe longer response times in information sets with strategic uncertainty.

If we just pool all decisions without considering who made the decision, then the average response time corresponding to when there is no strategic uncertainty (17) is longer than when there is (21.25). Figure 2 shows the cumulative distribution function of response time in information sets with and without strategic uncertainty. Visual inspection shows easily discernible differences indicating that response times are shorter in absence of strategic uncertainty. The Kolmogorov-Smirnov test detects a significant difference $(\mathrm{p}$-value $=0.008)$ between the two distributions.

The descriptive statistics in Table 3 aggregate observations on the individual level. It shows that average response time is considerably longer when there is strategic uncertainty. In fact, the Wilcoxon signed-rank test indicates a significant difference ( $\mathrm{p}$-value $=0.037$ ).

Overall, the previous results show strong evidence in favour of Hypothesis 


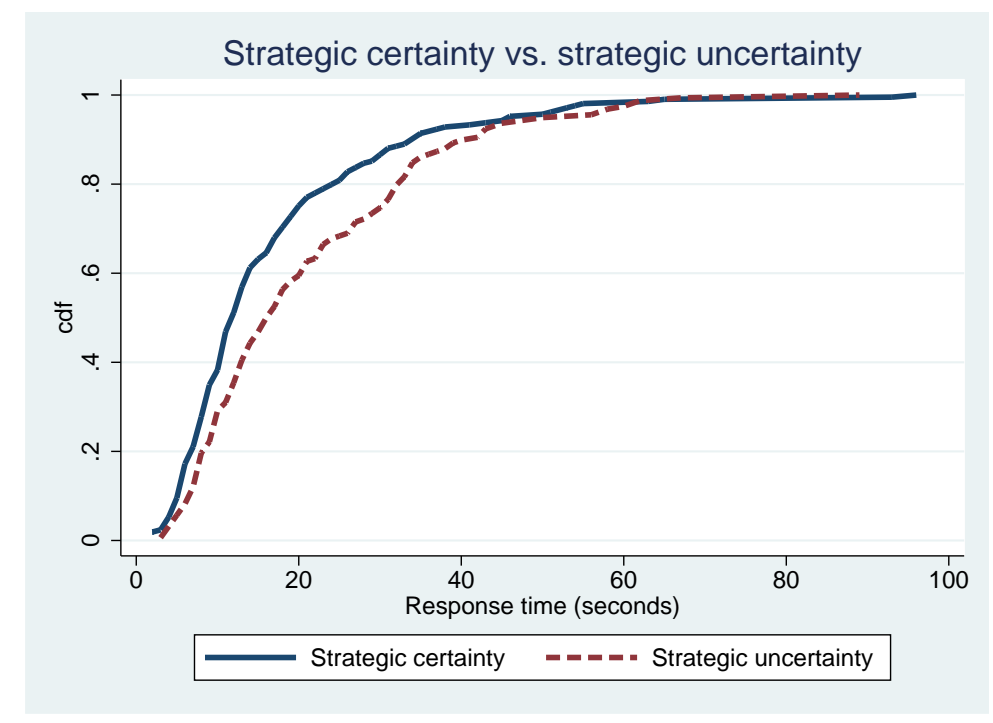

Figure 2: Cumulative distribution function of response times with and without strategic uncertainty when there is dominant strategy

1b, indicating that when considering strategic uncertainty the difficulty of the decision is associated with response time in information sets with a dominant strategy.

Result 1b - Strategic uncertainty and response time: We focus on information sets with a dominant strategy. In information sets with strategic uncertainty response time is longer than in information sets without strategic uncertainty, thus we cannot reject Hypothesis $1 \mathrm{~b}$.

\subsection{Response time and depositor decision}

Hypothesis 2a proposes that response time should correlate positively with optimal decisions in the information sets with dominant strategy. We find that subjects who optimally decided to keep the money in the bank needed on average 18.29 seconds to do so, while those who withdrew needed 24.15 seconds. The cumulative distribution function of response time in information sets with dominant strategy in Figure 3 confirms that those who decide to keep the money in the bank do so in less time than those who withdraw. According to the Kolmogorov-Smirnov test the difference is significant ( $\mathrm{p}$-value=0.043).

When decisions are aggregated on the individual level (see Table 2), we see the same pattern as with the pooled data. ${ }^{14}$ That is, those who chose optimally (and kept their funds in the bank) actually needed less time to make up there mind. The Wilcoxon signed-rank test reveals that the difference is not significant $(\mathrm{p}$-value $=0.6417)$.

\footnotetext{
${ }^{14}$ The number of observations depends on how many of the 60 participants chose at least once to keep her funds depositied / withdraw with or without dominant strategy. For instance, $\mathrm{N}=17$ in column 2 indicates that there were 17 participants who in information sets with dominant strategy chose to withdraw.
} 


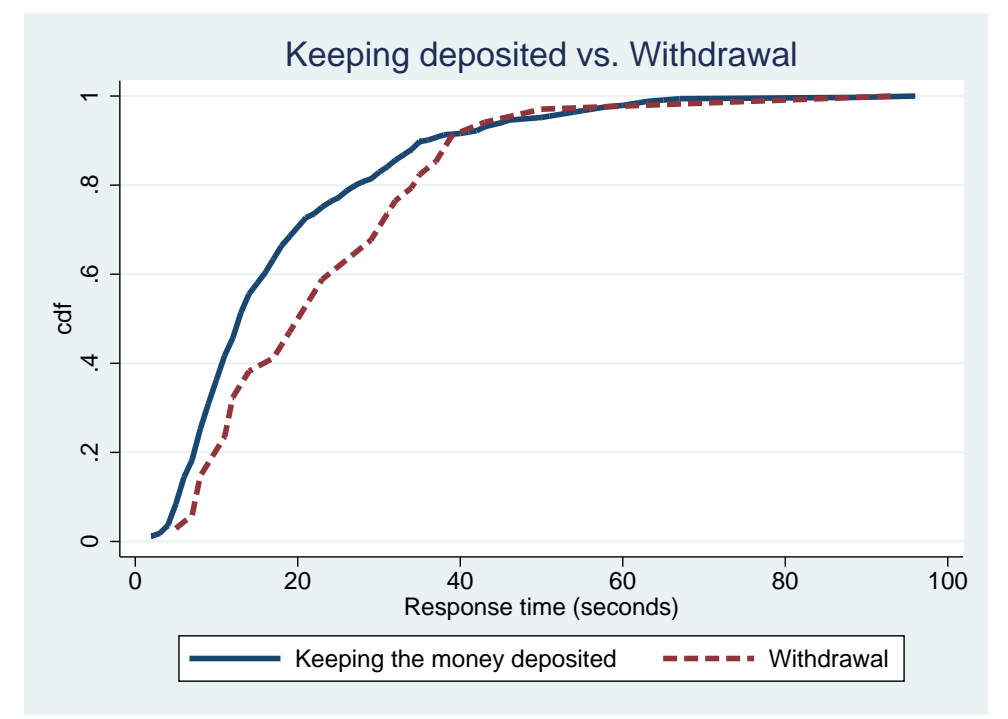

Figure 3: Cumulative distribution function of response times of withdrawal decisions with a dominant strategy

This evidence suggests that shorter response times associate with the (correct) decision of keeping the money in the bank when the decision is straightforward. We consider now two regressions represented in Table 4 . We estimate a logit model in which the dependent variable is if the depositor withdraws (decision $=1$ ) or not $($ decision $=0)$. The main explanatory variable in both regressions is response time that measures the seconds elapsed before the participant chose. In the first regression we consider information sets with and without dominant strategy and the dummy Dominant strategy shows if there is one. As our hypothesis formulates the potential interplay between strategic dominance and the effect of response time, we have also an interaction term (Resp. time * Dom. Strat.). In the second regression we only focus on the information sets with dominant strategy.

Since subjects played 15 rounds and they may be affected by the experience they had in previous rounds, we define the variable History as the percentage of previous rounds in which the subject observed the other patient depositor withdrawing. ${ }^{15}$ We also control by the variables in the questionnaire (cognitive abilities, gender and risk aversion).

The estimated standard errors in parentheses are corrected using the Bias Reduced Linearization (see Bell and McCaffrey (2002)) and control for matching group clustering. We report the marginal effects.

\footnotetext{
${ }^{15}$ Since the study by Garratt and Keister (2009), it is standard to control for experience in previous rounds.
} 


\begin{tabular}{|c|c|c|}
\hline VARIABLES & $\begin{array}{c}\text { (1) } \\
\text { Pooled data } \\
\text { Marginal effects }\end{array}$ & $\begin{array}{c}(2) \\
\text { Dominant strategy } \\
\text { Marginal effects }\end{array}$ \\
\hline Response time & $\begin{array}{c}0.00234^{* * *} \\
(0.000819)\end{array}$ & $\begin{array}{c}0.00169 * * * \\
(0.000642)\end{array}$ \\
\hline Dominant strategy & $\begin{array}{c}-0.327^{* * *} \\
(0.0664)\end{array}$ & \\
\hline Resp. time ${ }^{*}$ Dom. strat. & $\begin{array}{c}0.00141 \\
(0.00254)\end{array}$ & \\
\hline Cognitive abilities & $\begin{array}{c}0.0143 \\
(0.0346)\end{array}$ & $\begin{array}{l}-0.0170 \\
(0.0259)\end{array}$ \\
\hline Female & $\begin{array}{c}0.0248 \\
(0.0925)\end{array}$ & $\begin{array}{c}0.0115 \\
(0.0380)\end{array}$ \\
\hline Risk aversion & $\begin{array}{c}-0.000651 \\
(0.0332)\end{array}$ & $\begin{array}{r}-0.00251 \\
(0.0182)\end{array}$ \\
\hline History & $\begin{array}{c}-0.0515 \\
(0.135)\end{array}$ & $\begin{array}{l}-0.164 \\
(0.124)\end{array}$ \\
\hline Observations & 900 & 367 \\
\hline
\end{tabular}

Table 4: Regression analysis of the effect of response times on withdrawal decisions with a dominant strategy

In the first regression, the effect of response time is positive and significant, suggesting that overall longer response time leads to more withdrawals. However, being in an information set with a dominant strategy has a significant and negative effect, in line with the descriptive statistics that shows that participants were less likely to withdraw when there was a dominant strategy relative to when there was no $(22.4 \%$ vs. $46.2 \%)$. The interaction term is not significant, indicating that response time does not have a different effect depending on being in an information set with dominant strategy. When considering only decisions in information sets with dominant strategy, the effect of response time does not have the expected sign, and moreover it is significant. Therefore, longer response time tends to lead to worse decisions, ceteris paribus. The rest of the variables does not have a significant effect.

Result 2a: We do not observe a positive correlation between response time and optimal decisions in information sets with dominant strategy. In fact, the opposite holds. Thus, we reject Hypothesis 2a.

Hypothesis $2 \mathrm{~b}$ relates response time and optimal decisions when there is or is not strategic uncertainty. With strategic uncertainty, longer response time should correlate positively with optimal decisions. However, when there is no strategic uncertainty, longer response time may just indicate confusion and result in suboptimal choice.

Using pooled data, in the absence of strategic uncertainty, decisions of keeping the money in the bank took on average 16.28 seconds, while withdrawals 
needed 37.74 seconds. The cumulative distribution function of response time in information sets without strategic uncertainty in Figure 4 confirms that keeping the money in the bank required less time than withdrawing. The KolmogorovSmirnov test indicates that the difference is significant ( $\mathrm{p}$-value $=0.003)$.

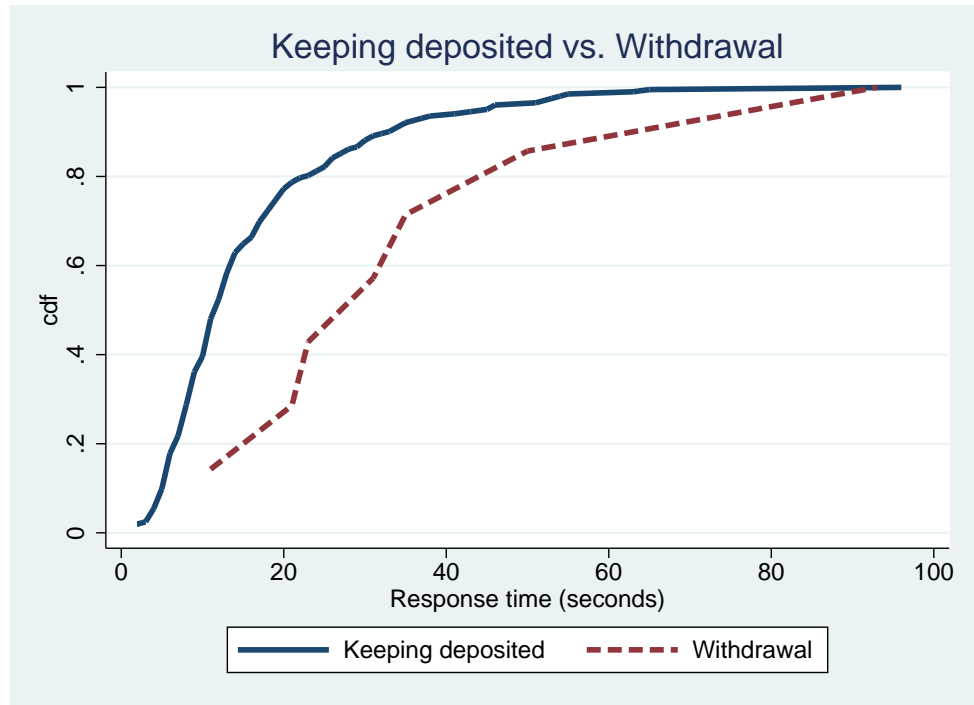

Figure 4: Cumulative distribution function of response times of withdrawal decisions without strategic uncertainty

If decisions are aggregated on the individual level (see Table 3), the same pattern as with the pooled data is observed. That is, those who chose optimally (and kept their funds in the bank) actually needed a lot (about 50\%) less time to make up their mind. Despite the sizable difference, the Wilcoxon signedrank test fails to detect a significant difference $(\mathrm{p}$-value $=0.1797)$, possibly due to the fact that there were only 3 participants who withdrew at least once in information sets with a dominant strategy and without strategic uncertainty.

Turning to the case with strategic uncertainty, decisions of keeping funds deposited took on average 21.38 seconds to do so which is somewhat longer than the 20.63 seconds needed by withdrawals. Figure 5 shows the cumulative distribution function corresponding to these cases. The Kolmogorov-Smirnov test does not detect any significant difference $(\mathrm{p}$-value $=0.8)$.

When considering the data aggregated on the individual level, again we observe that on average finding the optimal decision took more time than choosing the suboptimal alternative, in line with Hypothesis 2b. However, the Wilcoxon signed-rank test fails to detect a significant difference ( $p$-value $=0.2209$ ).

Table 5 shows the results of a logit model estimation where the dependent variable is if the depositor withdraws or not. The main explanatory variable is response time, and we control also by cognitive abilities, gender, risk aversion and history. In the first regression we consider information sets both with and without strategic uncertainty and the dummy Strat. uncert. indicates in which one we are. As our hypothesis formulates a potential interplay between strategic uncertainty and the effect of response time, we have also an interaction term (Resp. time $*$ Strat. uncert.). In the second / third regressions we consider 


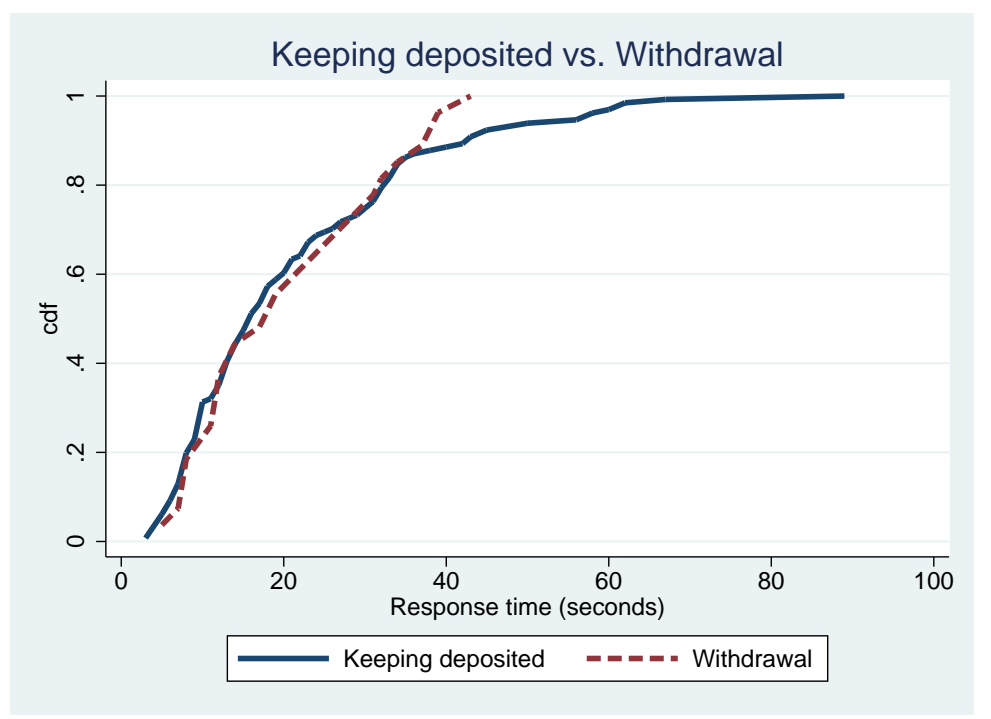

Figure 5: Cumulative distribution function of response times of withdrawal decisions with strategic uncertainty

cases without / with strategic uncertainty.

\begin{tabular}{|c|c|c|c|}
\hline VARIABLES & $\begin{array}{c}(1) \\
\text { Pooled data } \\
\text { Marginal effects }\end{array}$ & $\begin{array}{c}(2) \\
\text { Strategic Certainty } \\
\text { Marginal effects }\end{array}$ & $\begin{array}{c}(3) \\
\text { Strategic Uncertainty } \\
\text { Marginal effects }\end{array}$ \\
\hline Response time & $\begin{array}{c}0.00242^{* * *} \\
(0.000789)\end{array}$ & $\begin{array}{c}0.000111 \\
(8.93 \mathrm{e}-05)\end{array}$ & $\begin{array}{r}-0.000443 \\
(0.00161)\end{array}$ \\
\hline Strat. uncert. & $\begin{array}{c}0.241^{* * *} \\
(0.0728)\end{array}$ & & \\
\hline Resp. time $\mathrm{x}$ Strat. uncer. & $\begin{array}{c}-0.00262^{* *} \\
(0.00106)\end{array}$ & & \\
\hline Cognitive abilities & $\begin{array}{l}-0.0111 \\
(0.0159)\end{array}$ & $\begin{array}{c}0.00240 \\
(0.00251)\end{array}$ & $\begin{array}{l}-0.0803 \\
(0.0512)\end{array}$ \\
\hline Female & $\begin{array}{l}0.00629 \\
(0.0267)\end{array}$ & $\begin{array}{c}0.00675 \\
(0.00970)\end{array}$ & $\begin{array}{l}-0.0291 \\
(0.0766)\end{array}$ \\
\hline Risk aversion & $\begin{array}{r}-0.00302 \\
(0.0114)\end{array}$ & $\begin{array}{l}0.000822 \\
(0.00138)\end{array}$ & $\begin{array}{l}-0.0220 \\
(0.0343)\end{array}$ \\
\hline History & $\begin{array}{l}-0.145 \\
(0.106)\end{array}$ & $\begin{array}{l}-0.0314 \\
(0.0212)\end{array}$ & $\begin{array}{l}-0.230 \\
(0.236)\end{array}$ \\
\hline Observations & 367 & 209 & 158 \\
\hline
\end{tabular}

Table 5: Regression analysis of the effect of response times on withdrawal decisions with strategic certainty

The first column shows that when there is no strategic uncertainty, then longer response time predicts worse decisions (that is, withdrawal). This is in line with our hypothesis. Moreover, in the presence of strategic uncertainty we observe that withdrawals are more likely. However, the interaction term is 
negative, indicating that longer response times correlate with better decisions when there is strategic uncertainty, as conjectured in Hypothesis 2b. When considering the effect of response time on the withdrawal decisions separately for observations with and without strategic uncertainty, the sign of the effect is of the expected direction, but we do not observe any significant effect. The rest of the variables does not have a significant effect.

Overall, the sign of the effect of response time on the optimality of decisions is always in line with our Hypothesis $2 \mathrm{~b}$ and we also have in some cases statistical significance.

Result 2b: In information sets with strategic uncertainty, there is weak evidence that longer response times associate with better decisions. However, when there is no strategic uncertainty and decisions are obvious, then we find the opposite. Thus, we cannot reject Hypothesis $2 \mathrm{~b}$.

\section{Conclusion}

Our main objective in this paper was to see how response time affects decisionmaking in a bank-run set up. The underlying game that we study experimentally is a coordination game with two types, a sort of game in which the effect of response time has not been investigated. Interestingly, the game has information sets with and without dominant strategies and in the former set we may distinguish also information sets with and without strategic uncertainty. This richness in information sets allows us to study associations between the length of decision and the difficulty / optimality of decision. More concretely, we posit that decision is easier in information sets with a dominant strategy compared to information sets without. Hence, we expect to see longer response times in the latter set (Hypothesis 1a). Furthermore, in the former set we have clear optimal choices, so we expect that there longer response time associates with better decisions (Hypothesis 2a). Digging a level deeper, we conjecture that decisions are easier when there is no strategic uncertainty, so we expect that strategic uncertainty correlates positively with response time (Hypotesis 1b). Last, we conjecture that when decisions are really easy due to the presence of dominant strategy and the lack of strategic uncertainty, then response time does not predict well optimal decisions, because longer response times may only signal confusion and as a consequence suboptimal choices. On the contrary, when there is strategic uncertainty we expect response times to have explanatory power regarding the optimality of decisions (Hypothesis 2b).

We find no evidence for Hypotheses 1a and 2a. We speculate that it may be due to the fact that finding those optimal choices takes as long as forming beliefs about the other participants' choices and responding to those beliefs. We find convinving support for Hypotheses $1 \mathrm{~b}$ and $2 \mathrm{~b}$. Hence, similarly to BranasGarza et al. (2016) we find that the presence of strategic uncertainty is related to longer response times. Moreover, we show that response time associates positively / negatively with optimal decisions depending on the difficulty of the decision.

Overall, we find some evidence that longer response times lead to better decisions, but the important message of the paper is that it depends on the nature of the decision. In fact, when choice is trivial (in information sets with 
a dominant strategy and without strategic uncertainty), then longer response time associate with worse decisions, suggesting that longer response time is a signal of confusion and the lack of understanding the underlying decision. We find similar results with respect to the presence / absence of dominant strategy. However, when considering strategic uncertainty, then indeed the length of response time has predictive power. This is reassuring for the case of bank runs, as bank runs often emerge as a bad equilibrium in a coordination game between depositors. Our study shows that imposing a longer response time may lead to better decisions, that is to avoid the bank run equilibrium. The ensuing policy recommendation is clear: imposing time to think about withdrawal decisions in form of deposit freezes may help to curb the spread of bank runs. 


\section{References}

[1] Ai, C., \& Norton, E. C. (2003). Interaction terms in logit and probit models. Economics Letters, 80(1), 123-129.

[2] Arad, A., Rubinstein, A., 2012. Multi-dimensional iterative reasoning in action: The case of the Colonel Blotto game. Journal of Economic Behavior \& Organization 84, 571-585.

[3] Baba, N., McCauley, R., Ramaswamy, S., 2009. US dollar money market funds and non-US banks. BIS Quarterly Review, March.

[4] Bell, R. M., McCaffrey, D. F. (2002). Bias reduction in standard errors for linear regression with multi-stage samples. Survey Methodology, 28(2), 169-182.

[5] Bertrand, M., Morse, A., 2011. Information Disclosure, Cognitive Biases, and Payday Borrowing. Journal of Finance 66 (6), 1865-93.

[6] Branas-Garza, P., Meloso, D., Miller, L., 2016. Strategic Risk and Response Time Across Games. International Journal of Game Theory

[7] Choi, J. J., Laibson, D., Madrian, B. C., 2011. $\$ 100$ bills on the sidewalk: Suboptimal investment in 401 (k) plans. Review of Economics and Statistics, 93(3), 748-763.

[8] Crosetto, P., Filippin, A. (2016). A theoretical and experimental appraisal of four risk elicitation methods. Experimental Economics, 19(3), 613-641.

[9] Diamond, D. W., \& Dybvig, P. H. (1983). Bank runs, deposit insurance, and liquidity. Journal of Political Economy, 91(3), 401-419.

[10] Donders, F. C., 1868. Over de snelheid van psychische processe. Onderzoekingen gedaan in het Physiologisch Laboratorium der Utrechtsche Hoogeschool. Tweede reeks II, 92-120.

[11] Esponda, I., \& Vespa, E. (2014). Hypothetical thinking and information extraction in the laboratory. American Economic Journal: Microeconomics, $6(4), 180-202$.

[12] Frederick, S. (2005). Cognitive reflection and decision making. The Journal of Economic Perspectives, 19(4), 25-42.

[13] Friedman, M., 1953. Essays in Positive Economics. Chicago: University of Chicago Press.

[14] Garratt, R., Keister, T. (2009). Bank runs as coordination failures: An experimental study. Journal of Economic Behavior \& Organization, 71(2), 300-317.

[15] Gerardi, K., Goette, L., Meier, S., 2013. Numerical ability predicts mortgage default. Proceedings of the National Academy of Sciences, 110(28), 11267-11271.

[16] Gneezy, U., Potters, J. (1997). An experiment on risk taking and evaluation periods. The Quarterly Journal of Economics, 112(2), 631-645. 
[17] Gorton, G., Metrick, A., 2012. Securitized banking and the run on repo. Journal of Financial Economics 104 (3), 425-451.

[18] Ivashina, V., Scharfstein, D., 2010. Bank lending during the financial crisis of 2008. Journal of Financial Economics 97 (3), 319-338.

[19] Jimenez, N., Rodriguez-Lara, I., Tyran, J. R., \& Wengström, E. (2018). Thinking fast, thinking badly. Economics Letters, 162, 41-44.

[20] Kahneman, D., 2011.Thinking, Fast and Slow (New York: Farrar, Straus, Giroux)

[21] Kinateder, M., Kiss, H. J. (2014). Sequential decisions in the Diamond-Dybvig banking model. Journal of Financial Stability, 15, 149-160.

[22] Kiss, H. J., Rodriguez-Lara, I., Rosa-Garcia, A., 2014a. Do social networks prevent or promote bank buns? Journal of Economic Behavior and Organization 101, 87-99.

[23] Kiss, H. J., Rodriguez-Lara, I., Rosa-Garcia, A., 2014b. Do women panic more than men? An experimental analysis of financial decisions. Journal of Behavioral and Experimental Economics 52, 40-51.

[24] Kiss, H. J., Rodriguez-Lara, I., \& Rosa-García, A. (2016). Think twice before running! Bank runs and cognitive abilities. Journal of Behavioral and Experimental Economics, 64, 12-19.

[25] Korniotis, G., Kumar, A., 2010. Cognitive Abilities and Financial Decisions. In H. Kent Baker and John Nofsinger (eds.) Behavioral Finance, Hoboken, NJ: John Wiley \& Sons, Inc.

[26] Lotito, G., Migheli, M., Ortona, G., 2013. Is cooperation instinctive? Evidence from the response times in a public goods game. Journal of Bioeconomics 15, 123-133.

[27] Ngangoue, K., \& Weizsacker, G. (2015). Learning from unrealized versus realized prices.

[28] Piovesan, M., Wengström, E., 2009. Fast or fair: A study of response times. Economics Letters 105(2), 193-196.

[29] Rand, D. G., Greene, J. D., Nowak, A., 2012. Spontaneous giving and calculated greed. Nature 489(7416), 427-430.

[30] Rubinstein, A., 2007. Instinctive and Cognitive Reasoning: A Study of Response Times. The Economic Journal 117, 1243-1259.

[31] Rubinstein, A., 2013. Response time and decision making: An experimental study. Judgment and Decision Making 8(5), 540-551.

[32] Shafir, E., \& Tversky, A. (1992). Thinking through uncertainty: Nonconsequential reasoning and choice. Cognitive psychology, 24(4), 449-474.

[33] Simon, H. A., 1976. From substantive to procedural rationality. In T.J. Kastelein, S.K. Kuipers, W.A. Nijenhuis, and G.R. Wagenaar (Eds.), 25 Years of Economic Theory, pp. 65-86, Boston, MA: Springer US. 
[34] Spiliopoulos, L., Ortmann, A., (2017). The BCD of response time analysis in experimental economics. Experimental Economics, https://doi.org/10.1007/s10683-017-9528-1

[35] Tinghög, G., Andersson, D., Bonn, C., Böttiger, H., Josephson, C., Lundgren, G., Vastfjall, D., Kirchler, M., Johannesson, M., 2013. Intuition and cooperation reconsidered. Nature 498(7452), E1-E2.

[36] Van Rooij, M. C., Lusardi, A., Alessie, R. J., 2011. Financial literacy and retirement planning in the Netherlands. Journal of Economic Psychology, 32(4), 593-608. 


\section{Appendix A: Instructions ${ }^{16}$}

\section{Welcome to the experiment!}

This experiment aims to study decision making; we are not interested in your particular choices but are focusing on the average behavior of individuals. Therefore, during the experiment, you will be treated anonymously. Neither the experimenters nor the people in this room will ever know your particular choices.

You will find the instructions on the computer screen explaining how the experiment will unfold. The instructions are the same for all participants in the laboratory and will be read aloud by the experimenters. It is important for you to understand the experiment before starting, as the money that you will earn will depend on your choices. You also have a copy of the instructions on your table.

Should you have any problem during the experiment, please raise your hand and remember that you are not allowed to speak with anyone except the experimenter.

\section{Number of rounds}

This experiment has 18 rounds in total. The first 3 rounds are intended for you to become familiar with the software. The remaining 15 rounds will be used to determine your final payoff, so please be sure that you understand the experiment before starting the 4th round. This understanding will help you to earn more money.

\section{Deposits}

At the beginning of each round, you will be provided a certain amount of money (80 ECUs) to be deposited in a bank. The bank in which you will invest your money will be formed by 3 depositors: one of them is you, one is someone else in this room and the third depositor is simulated by the computer. Therefore, the bank in which you deposit your money will have 240 ECUs per round in total.

\section{Decisions and earnings}

In principle, your decision involves choosing whether to withdraw your money from the common bank in the first period or to wait until the second period, considering that your earnings will depend not only on your choice but also on other depositors' choices. It is important that you know that the computer will always withdraw its money; thus, your earnings in each round will depend only on your choice and the choice of the other depositor in this room.

Specifically, if you both wait until the second period to withdraw your money, you will receive 140 ECUs, corresponding to your initial investment (80 ECUs) plus interest generated during the first period (during which you decided to wait).

If only one of you withdraws the money, then the one who withdraws receives 100 ECUs (which is the same amount that the computer will take in this case).

\footnotetext{
${ }^{16}$ Instructions are originally in Spanish.
} 


\begin{tabular}{|c|c|c|c|}
\cline { 3 - 4 } \multicolumn{2}{c|}{} & \multicolumn{2}{c|}{$\begin{array}{c}\text { In you decide to wait in the first year and } \\
\text { withdraw in the second, the... }\end{array}$} \\
\hline $\begin{array}{c}\text { Number of previous } \\
\text { withdrawals }\end{array}$ & $\begin{array}{c}\text { If you withdraw the } \\
\text { first year }\end{array}$ & $\begin{array}{c}\text { If you both wait and } \\
\text { only the computer } \\
\text { withdraws }\end{array}$ & $\begin{array}{c}\text { If, in addition to the } \\
\text { computer, the other } \\
\text { depositor withdraws }\end{array}$ \\
\hline 0 & 100 & 140 & 60 \\
\hline 1 & 100 & 140 & 60 \\
\hline 2 & 40 & Not applicable & 60 \\
\hline
\end{tabular}

Figure 6:

The depositor who waits will receive 60 ECUs (corresponding to the remaining amount in the bank after two withdrawals - 40 ECUs plus an additional 20 ECUs of interest).

Finally, it might be the case that both of you withdraw your money in the first period. As a result, your earnings will depend on the available amount of money in the bank and your position in line. Therefore, if you are at Position 1 or Position 2 in line and decide to withdraw, then you will receive 100 ECUs; however, if you are the last one in line (Position 3), then only 40 ECUs remain in the bank, and you will receive that amount.

Therefore, your payoffs can be summarized in the following table:

Please remember that the depositor simulated by the computer will always withdraw its money in the first period.

Before beginning, please consider the following:

1. The person with whom you are linked will change in every round. As a result, do not assume that you are going to play the entire game with the same person.

2. You will always know your position in line, but this position might change in each round. In particular, you have the same probabilities of being in Position 1, Position 2 or Position 3. The same is true for the computer's position.

3. In each round, you will have different information about what the other depositors at your bank have chosen. Therefore, in some cases, you will know what has happened before you arrived at the bank (the number of wait and withdrawal decisions), but in other cases, you will not have this information. When you make your choice, you will also know whether someone else will observe your action. It may be in your interest to consider this information when making your decision. This information will appear on the left-hand side of the computer screen.

E.g.: You are in Position 1. The depositors in Position 2 and Position 3 will observe your action.

E.g.: You are in Position 2. The depositor in Position 1 has chosen to wait. The depositor in Position 3 will not observe your action.

On the right-hand side of your screen, a small graph shows with whom you are linked (that is, the person whom you observe and who will observe you). If there is no link between two depositors, then the text on the screen indicates that the depositor who decides later cannot observe the action of the other depositor. The symbol "?" indicates that you do not know whether the other two depositors are linked. 


\section{Final payoff}

When the experiment ends, we randomly choose one of the 15 rounds and pay you according to the earnings from that round. We convert your earnings in that round at a rate 10 ECUs $=1$ euro.

We will now start with the first three rounds. At the end of these three rounds, you can ask any questions to ensure that you understand the procedure. If you have any doubts after the first three rounds, please raise your hand and remain silent. You will be attended by the experimenters as soon as possible. Talking is not allowed during this experiment. 